\title{
White Paper:
}

\section{US Law and International Interlibrary Loan}

\author{
Brandon Butler, Director of Public Policy Initiatives, \\ Association of Research Libraries \\ Kenneth D. Crews, Director, Copyright Advisory Office, \\ Columbia University Libraries \\ Donna Ferullo, Director of the University Copyright Office, \\ Associate Professor of Library Science, Purdue University Libraries \\ Kevin L. Smith, Director of Scholarly Communications, \\ Duke University Libraries
}

\section{Introduction}

arious recent events have raised questions about the proper scope of interlibrary loan (ILL) arrangements with non-US institutions, particularly the ability of a library to send copies of materials to nonUS libraries. We believe that US copyright law supports the ability of domestic libraries to participate in ILL arrangements and to send copies of some copyrighted works to foreign libraries, provided the libraries meet the requirements of the law. Although the law is not necessarily explicit about the conditions for sending copies of works through ILL, a few simple steps taken by libraries should provide greater assurance that the arrangements are serving the needs of libraries, researchers, and copyright owners.

\section{Relevant Legal Provisions}

Participation in ILL arrangements is a well-established practice in libraries in many countries. US copyright law allows libraries to make and distribute copies of copyrighted works in connection with ILL arrangements under Section 108 (Reproductions by Libraries and Archives) ${ }^{1}$ and Section 107 (Fair Use). License agreements may constrict or augment the rights of libraries to share materials as part of ILL arrangements. Nevertheless, Section 108 is a leading legal support for the reproduction and distribution of copyrighted works in ILL. 


\section{Status of the CONTU Guidelines}

Many libraries rely on the 1978 guidelines issued by the Commission on New Technological Uses of Copyrighted Works (CONTU)—specifically, the "Rule of Five" ${ }^{\prime 2}$ - to provide a framework for complying with Section 108(g)(2), which could bar libraries from using ILL arrangements as a "substitute for a subscription to or purchase of" copyrighted works. While CONTU and the Rule of Five can be helpful for libraries in establishing procedures for ILL, they are only guidelines and do not have the full force and effect of the law. Indeed, the Conference Report on the 1976 Copyright Act, which endorsed the guidelines, also acknowledged that they "are not intended to be limiting or determinative in themselves or with respect to other situations, and that they deal with an evolving situation that will undoubtedly require their continuous reevaluation and adjustment." ${ }^{3}$ In short, CONTU is not the law, and Congress and the CONTU drafters agreed that the law allows more than CONTU contemplates.

\section{Responsibilities of US Libraries}

Libraries that make and supply copies in an ILL arrangement generally look for confirmation from any requesting library that it is acting within the limits of Section 108. The fulfilling library as a practical matter relies on the good faith of the requesting library in order to assure that its services are within the scope of the law. In a typical ILL transaction, a requesting library seeks a copy from a fulfilling library of a work that is in the fulfilling library's collection. The requesting library is in the best position to know whether making the copy satisfies a statutory exception (e.g., whether it is a "substitute for a subscription or purchase"), yet the fulfilling library may have possible liability exposure (because it makes and distributes copies). Therefore, while the fulfilling library can watch for red flags that indicate bad faith, it must typically rely on requesting libraries' representations that all ILL requests are legitimate.

Because the Berne Convention and other international copyright agreements do not specify any standards for ILL, nations have considerable discretion about the terms of allowable reproduction and distribution, or even whether to allow ILL activities at all. As a result, the law on such matters varies greatly from one country to the next. In the context of a request from a foreign library, a US library that fulfills the request is still making the copy in the US and therefore is subject to US law. The fulfilling library accordingly may still want assurances from foreign partners that can help the US library determine whether the services may run afoul 
of US law. While foreign institutions may not be bound by the same legal rules as US libraries, there are many ways a fulfilling library can be assured that its foreign partners' requests are legitimate. Sources of assurance include shared library practices as well as formal commitments and representations from foreign partners.

The proper scope and function of ILL are embedded in well-established practices that have been openly integrated into professional standards and have been widely known to and acknowledged by authors, publishers, and others for years. Grounded in practical concerns as well as respect for copyright, these practices support the use of ILL ordinarily only for materials the requesting library would not otherwise license or purchase. ILL is typically an inefficient substitute for purchase or subscription where the latter is truly justified, and to the extent that it prevents a library from acquiring relevant materials for its own collection, abuse of ILL undermines library mission. Quite simply, a high volume of ILL requests for a particular item is a reliable signal of scholarly interest that should lead a research library to acquire the item for its own collection. For these reasons, academic and research libraries that follow best practices will not engage in abuse of an ILL arrangement, regardless of variations in technical legal regimes.

Fulfilling libraries also obtain assurances from international partners by formal representation. For example, most ILL request forms contain a box that requesting libraries check to indicate that their request is in compliance with US copyright law or CONTU guidelines. US libraries have no reason to believe foreign partners misrepresent themselves on these forms, which accompany each ILL request. If there is any indication of confusion, it may be helpful to explain to foreign ILL partners that US law bars domestic libraries from reproduction and lending that violates Section 108 or is not within fair use, with a clear statement that these two provisions may apply. It may also help to make the representations more explicit. For example, request forms could be changed to include verification similar to the following:

This request is in compliance with US Copyright Law, including either Section 107 (fair use) or Section 108(g)(2), which provides that requests will not be made "in such aggregate quantities as to substitute for a subscription to or purchase of such work." The requesting library represents that it complies with US law and that receiving the copy will not violate the copyright, importation, or other laws of the requesting library's country. 
Such a verification, incorporating the key language of 108(g)(2), would reduce the likelihood that a foreign partner would check a box without understanding its meaning. Requesting libraries can further support the legitimacy of their requests by keeping records of requests. These procedures can help ensure that the requesting library will be able to demonstrate that its requests over time have satisfied Section 108 or Section 107.

The measures described above should be sufficient to provide domestic libraries with the confidence they need to participate in an ILL system that involves foreign institutions. With adequate assurances in place, a US library may engage in ILL arrangements with foreign institutions.

1 Specifically, Section 108(d) allows for copying of certain materials by one library for the users of another library, and Section 108(g)(2) states, "...[N]othing in this clause prevents a library or archives from participating in interlibrary arrangements that do not have, as their purpose or effect, that the library or archives receiving such copies or phonorecords for distribution does so in such aggregate quantities as to substitute for a subscription to or purchase of such work."

2 The Rule of Five bars fulfilling requests by the same library within a single calendar year for more than five articles from the previous five years' worth of the same periodical. It also bars more than five requests for copies from any copyrighted non-periodical work during a calendar year. The rule is silent as to the treatment of articles more than five years old. It is also silent as to non-periodical works.

3 Discussion of the CONTU guidelines appears in H.R. Rep. No. 94-1733 at 70-74 (1976) (Conf. Rep.). In reality, reevaluation and adjustment of the guidelines has not occurred.

(c) 2011 Brandon Butler, Kenneth D. Crews, Donna Ferullo, Kevin L. Smith

This article is licensed under a Creative Commons Attribution-NoncommercialShare Alike 3.0 United States License. To view a copy of this license, visit http: / / creativecommons.org/licenses/by-nc-sa/3.0/us/.

To cite this article: Brandon Butler, Kenneth D. Crews, Donna Ferullo, and Kevin L. Smith. "White Paper: US Law and International Interlibrary Loan." Research Library Issues: A Quarterly Report from ARL, CNI, and SPARC, no. 275 (June 2011): 15-18. http://publications.arl.org/rli275/. 